\title{
Validating the IT Value Model: A Case of Cloud Computing Server
}

\author{
Abdullah Saad Al-Malaise Al-Ghamdi \\ Faculty of Computing and Information Technology, \\ King Abdulaziz University, Jeddah, \\ Kingdom of Saudi Arabia
}

\begin{abstract}
Current advancement in Information Technology (IT) support the organizations to achieve their business objectives efficiently. The competitive environment always stressing the organizations to invest more on installing and implementing the updated IT resources. This study is mainly focuses on measuring the impact of those IT resources on organization. Initially, the researchers categorized the IT evaluation using two perspective; financial and non-financial. Apart from financial benefits IT project can generate, assessing the nonfinancial values is the main objective of this paper. The research approach undertaken in this study is to select and validate the IT Value Model on already implemented IT project. Firstly, we reviewed, selected and refined the framework proposed previously in literature review. Furthermore, the selected framework validated using real world case study of Cloud Computing Server (CCS). The results indicates that the non-financial values can be categorized and measured as strategic, informational, transactional and transformational. The framework validated and generate positive output as discussed in the last section. This study can be useful for the enterprises to assess the post implementation impact of IT projects on organizational business objectives using IT value model.
\end{abstract}

\section{Keywords}

IT Project, IT Project Evaluation, Non-Financial Benefits, IT Value Model

\section{INTRODUCTION}

In current market scenario IT plays significant role for the development of profitable customer oriented business strategies. Organizations are spending billions of dollars on IT resources [1] for building organizational structure to be competent among partners competitors. Those IT investments create major impact on organizational business objectives. As [2] highlighted that IT investments are major source of doing business in an efficient manner, whereas it highly influence the economic growth of company. Despite the benefits achieve through IT resources, measuring the impact of those resources is the major challenge for the companies.

The literature review proved that in order to justify the IT investment comply the business objective, there can be several ways [3]. Mainly, [4] described the method for measuring IT investment which can be categorized as pre and post evaluation. Furthermore, researchers also explained the IT evaluation based on financial and non-financial perspectives [3]. [5] elaborate further that IT have direct and indirect effects on enterprises. Whereas direct effects also known as financial benefits [6] which assess through methodologies like Return on Investment (ROI) [7]. On the other side indirect benefits also known as non-financial benefits [6] which measure through multi-dimensional methodologies such as Value on Investment (VOI) [7].

In previous researches a list of multi-dimensional impacts discussed, which are directly or indirectly associated with IT project. Firm performance [8, 9], productivity [10], effectiveness [11] are some of the multi-dimensional impact of IT project which are associated with organizational business strategies. Organizations are getting those impact based on different types of business objectives in the form of IT projects such as enterprise resource planning [12, 13, 14], customer relationship management [15] sometime applying additional functionalities on implemented projects $[16,17$, $18]$.

IT projects evaluation is a complex issue, where multidimensional impact of IT resources make the procedure even more complicated. This study initially investigated the possible ways to asses IT project from different perspective such as financial and non-financial. Whereas, the main objective of this research is to validate the IT Value Model using real world case study to understand the purpose and implementation of framework presented by [19].

\section{SELECTION OF FRAMEWORK FOR IT PROJECT EVALUATION}

The research methodology applied in this paper is to review the literature review to find out the proposed framework for IT project evaluation. Several researchers have proposed IT measurement methodologies based on multiple criterion [20]. [21] suggested the idea of measuring the IT project after implementation in two ways; direct cost return and indirect cost return. Some public organizations have also proposed the idea for measuring their IT project but the model are not available for other companies [22]. [23] discussed the different kind of methodologies can be applied in business organizations in order to maintain their project cost by measuring them after implementation.

Irrespective of assessing IT project based on financial return, this study is focused on the non-financial benefits generated from IT projects. Therefore, [19] elaborate the idea of benefits return are same as value return from IT resources. Measuring non-financial benefits or values is latest trends in the market where companies want to review the impact of IT resources on customer and employees. [24, 25] are the researches where they used framework for assessing the values generated from IT resources based on organizational business objective. The scenario presented in those researches highlighted that the company's strategies have positive link with IT resources, where each IT resource generates number of values for the organization, that are originally extracted from customer and employees point of view. 
Based on the business objectives, [26] proposed a framework which can assess the IT projects using four major dimensions; transactional, informational, strategic, and infrastructure. Each dimension associated with number of items, investigating those items can provide comprehensive details about IT project's impact on enterprises. Furthermore, the IT Value Model, framework selected and validated in this study was earlier developed using the surveys responses collected from Brazilian firm, which further analyzed through factor analysis, whereas this study selected the final version of the model as mentioned in Table-1[19]. The graphical representation of the model shown in Figure-1.

Table 1. Dimensions of IT Value Model [19]

\begin{tabular}{|c|c|c|c|}
\hline No. & Main Benefits & No. & Sub-Items \\
\hline \multirow{4}{*}{1} & \multirow{4}{*}{$\begin{array}{l}\text { Strategic } \\
\text { Benefits }\end{array}$} & 1 & $\begin{array}{l}\text { Establishing useful } \\
\text { links with other } \\
\text { organizations }\end{array}$ \\
\hline & & 2 & $\begin{array}{l}\text { Improving customer } \\
\text { relations }\end{array}$ \\
\hline & & 3 & $\begin{array}{l}\text { Providing better } \\
\text { products or services to } \\
\text { customers }\end{array}$ \\
\hline & & 4 & $\begin{array}{l}\text { Improving information } \\
\text { for strategic planning }\end{array}$ \\
\hline & & & \\
\hline \multirow{3}{*}{2} & \multirow{3}{*}{$\begin{array}{l}\text { Informational } \\
\text { Benefits }\end{array}$} & 1 & $\begin{array}{l}\text { Enabling faster access } \\
\text { to information }\end{array}$ \\
\hline & & 2 & $\begin{array}{l}\text { Enabling easier access } \\
\text { to information }\end{array}$ \\
\hline & & 3 & $\begin{array}{l}\text { Improving information } \\
\text { accuracy }\end{array}$ \\
\hline & & & \\
\hline \multirow{4}{*}{3} & \multirow{4}{*}{$\begin{array}{l}\text { Transactional } \\
\text { benefits }\end{array}$} & 1 & $\begin{array}{l}\text { Reducing operating } \\
\text { costs }\end{array}$ \\
\hline & & 2 & $\begin{array}{l}\text { Reducing } \\
\text { communication costs }\end{array}$ \\
\hline & & 3 & $\begin{array}{l}\text { Reducing the marginal } \\
\text { cost of business unit's } \\
\text { in IT }\end{array}$ \\
\hline & & 4 & Reduction of IT costs \\
\hline & & & \\
\hline \multirow{4}{*}{4} & \multirow{4}{*}{$\begin{array}{l}\text { Transformational } \\
\text { Benefits }\end{array}$} & 1 & $\begin{array}{l}\text { An improved skill level } \\
\text { for employees }\end{array}$ \\
\hline & & 2 & $\begin{array}{l}\text { Developing new } \\
\text { business plans }\end{array}$ \\
\hline & & 3 & $\begin{array}{l}\text { Improving business } \\
\text { models }\end{array}$ \\
\hline & & 4 & $\begin{array}{l}\text { Improving business } \\
\text { flexibility }\end{array}$ \\
\hline
\end{tabular}

\section{VALIDATION OF IT PROJECT'S EVALUATION FRAMEWORK}

In this study, the final step is to validate the selected framework presented in Figure-1, using real world system. For this, the selected organization is customer oriented, which largely invested on IT resources to improve their business processes. Combination of IT applications support the operational and business activities which ultimately enhance the working environment, employee productivity and profit of the organization. The system selected in this research is known as cloud computing server (CCS) implemented to build IT infrastructure to provide online resources and products for their customers. A large infrastructure created with the combination of software and hardware to provide multiple online services to customer, employees and partners.

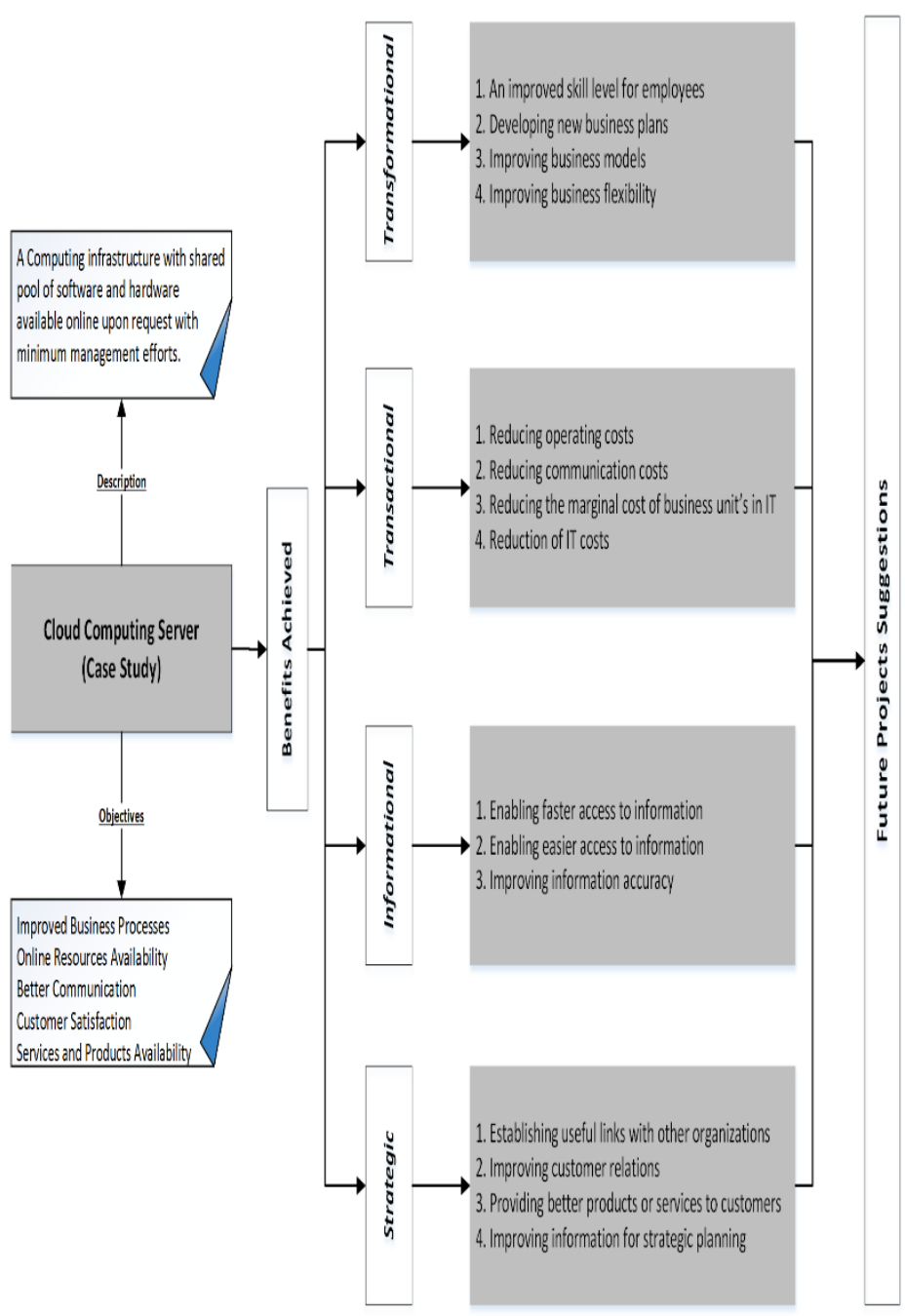
Fig 1: Proposed Validation Framework of IT Value Model
adapted from [19]

CCS is belongs to the organization having more than 500 employees and thousands of customers connected with online portal. The system offers number of services at the same time it can support hundreds of request on daily bases effectively. During the validation period, number of questions investigated from system manager, project manager, and IT director of the company. The summary of discussion collected during validation process summarized in Table-2. The main idea of this validation process is to understand the benefits achieved after implementing this system. Evaluation of IT project is the main objective of this research. Therefore, the framework selected in this study is basically developed for measuring the post implementation non-financial benefits from any IT project. Furthermore, the matrix (Equation 1) has been proposed to measure the IT project non-financial benefits.

Benefit's Calculation $=$

$\{[$ Strategic $($ Str $1+\operatorname{Str} 2+\operatorname{Str} 3+\operatorname{Str} 4)]+$ [Informational (Info $1+\operatorname{Info} 2+\operatorname{Info} 3)]+$ $[$ Transactional $(\operatorname{Tr} s 1+\operatorname{Tr} s 2+\operatorname{Tr} s 3+\operatorname{Tr} s 4)]+$ [Transformational $(\operatorname{Tr} f 1+\operatorname{Tr} f 2+\operatorname{Tr} f 3+\operatorname{Tr} f 4)]\}$

[Equation-1] 
Table 2. Summary of Benefits Achievement after Implementation of CCS in Case Study

\begin{tabular}{|c|c|c|c|}
\hline S.No. & Main Benefits & Sub-Items & $\begin{array}{l}\text { Summary of Investigation and Responses Collected from Case } \\
\text { Study } \\
\underline{\text { A Case of Cloud Computing Server (CSS) }}\end{array}$ \\
\hline \multirow[t]{4}{*}{1} & Strategic Benefits & $\begin{array}{l}\text { Establishing useful links } \\
\text { with other organizations }\end{array}$ & $\begin{array}{l}\text { The CCS specially built for providing online facilities to making } \\
\text { strong relationship between customers and employees and we } \\
\text { have successfully achieved this objective. } \\
\text { The cloud server facility helped our main objective of the } \\
\text { organization by establishing valuable links between different } \\
\text { partner organizations. }\end{array}$ \\
\hline & & $\begin{array}{l}\text { Improving customer } \\
\text { relations }\end{array}$ & $\begin{array}{l}\text { Yes, this is one of the most important benefit we achieved through } \\
\text { this system. Customers acknowledged our system very positively. } \\
\text { Making resources available all the time created ease for the } \\
\text { customer, where they do not need to visit physically to our } \\
\text { locations. }\end{array}$ \\
\hline & & $\begin{array}{l}\text { Providing better products or } \\
\text { services to customers }\end{array}$ & $\begin{array}{l}\text { The cloud services helped us to improve marketing campaign } \\
\text { more effectively. } \\
\text { The feedback from the customers actually enhanced the capability } \\
\text { of the system by offering online services and products to } \\
\text { customers in an efficient manner. }\end{array}$ \\
\hline & & $\begin{array}{l}\text { Improving information for } \\
\text { strategic planning }\end{array}$ & $\begin{array}{l}\text { Initially, this system installed to propose online facilities to all } \\
\text { type of stakeholders. Partially it supported the strategic planning } \\
\text { process but this kind of strategic benefit does not fully match with } \\
\text { our system. }\end{array}$ \\
\hline \multirow[t]{3}{*}{2} & $\begin{array}{l}\text { Informational } \\
\text { Benefits }\end{array}$ & $\begin{array}{l}\text { Enabling faster access to } \\
\text { information }\end{array}$ & $\begin{array}{l}\text { Yes, the CCS increased the capability of storing extensive data. } \\
\text { With the scalable data storage, it makes the business processes to } \\
\text { run faster. } \\
\text { Accessible and faster access to the products, services and other } \\
\text { information is the main aim of building cloud server. Moreover, } \\
\text { yes we have achieved this objective successfully. }\end{array}$ \\
\hline & & $\begin{array}{l}\text { Enabling easier access to } \\
\text { information }\end{array}$ & $\begin{array}{l}\text { Using this system, customers and organizations can reach to the } \\
\text { information easily. } \\
\text { Shared storage places sorted the procedure of distributing inter- } \\
\text { departmental data within organizations. } \\
\text { Online portal provides easier access to the data resources and } \\
\text { applications distributed over the cloud. }\end{array}$ \\
\hline & & $\begin{array}{l}\text { Improving information } \\
\text { accuracy }\end{array}$ & $\begin{array}{l}\text { The system inaugurated with all precautions and validation to } \\
\text { generate accurate information. } \\
\text { The clear indications highlighted after this system's } \\
\text { implementation that it accelerated the business and its processes } \\
\text { more intelligently because of proper information. }\end{array}$ \\
\hline 3 & $\begin{array}{l}\text { Transactional } \\
\text { benefits }\end{array}$ & Reducing operating costs & $\begin{array}{l}\text { The system we are talking about assisted in managing the } \\
\text { operational processes. } \\
\text { Some online operational processes has improved and reduced } \\
\text { operating cost, rather manufacturing department has no link with } \\
\text { cloud computing server. }\end{array}$ \\
\hline
\end{tabular}




\begin{tabular}{|c|c|c|c|}
\hline & & $\begin{array}{l}\text { Reducing communication } \\
\text { costs }\end{array}$ & $\begin{array}{l}\text { One of the promising benefit achieved with this system is online } \\
\text { available services and products for all type of stakeholders. } \\
\text { Yes, the cloud facility reduced communication cost effectively. } \\
\text { Increasing space can improve the performance even better. }\end{array}$ \\
\hline & & $\begin{array}{l}\text { Reducing the marginal cost } \\
\text { of business unit's in IT }\end{array}$ & $\begin{array}{l}\text { Many of the other resources saved due to building an online } \\
\text { server. } \\
\text { Overall, the marginal cost of IT unit reduced by providing } \\
\text { resources and products online. For this, we saved money by not } \\
\text { purchasing additional hardware and software. }\end{array}$ \\
\hline & & Reduction of IT costs & $\begin{array}{l}\text { Furthermore, yes the system has created positive impact on } \\
\text { reduction the overall budget of purchasing additional IT resources. } \\
\text { The saving of this IT cost enables to invest this amount to improve } \\
\text { business processes and manufacturing department. }\end{array}$ \\
\hline \multirow[t]{4}{*}{4} & $\begin{array}{l}\text { Transformational } \\
\text { Benefits }\end{array}$ & $\begin{array}{l}\text { An improved skill level for } \\
\text { employees }\end{array}$ & $\begin{array}{l}\text { The system has no impact on improving the employee skills. The } \\
\text { system just provide ease to the employees to deal with customers } \\
\text { and other type of stakeholders though online portal and standard } \\
\text { procedure. }\end{array}$ \\
\hline & & $\begin{array}{l}\text { Developing new business } \\
\text { plans }\end{array}$ & $\begin{array}{l}\text { One of the major transformation formed after implementing this } \\
\text { server is developing new business plans. } \\
\text { The online portal generated number of datasets, while analyzing } \\
\text { those datasets enhanced the business plans, which ultimately } \\
\text { increase the profit of the organization. }\end{array}$ \\
\hline & & Improving business models & $\begin{array}{l}\text { The CCS has sufficiently enhanced the business model, processes } \\
\text { and business routine's capability. } \\
\text { The business models and processes reengineered based on the } \\
\text { dataset generated through users and customers feedback. }\end{array}$ \\
\hline & & $\begin{array}{l}\text { Improving business } \\
\text { flexibility }\end{array}$ & $\begin{array}{l}\text { The system offered several ways to doing business. Flexible } \\
\text { business environment helped us to generate more profits to the } \\
\text { organization. } \\
\text { Online updated materials increase the credibility of resources and } \\
\text { products with improved business flexibility. }\end{array}$ \\
\hline
\end{tabular}

\section{CONCLUSION}

IT industry largely impacts the business organization by providing different kinds of resources such as information systems, enterprise system, cloud computing and others. In this study we discussed about kinds of impact IT project creates on organizational business objective. The literature review suggested that IT project generates different kinds of financial and non-financial benefits based on organizational objectives. Measuring non-financial values using IT Value Model was the main aim of this study which has been validated using real world case study. The measuring dimensions presented in the model are named as strategic, informational, transactional and transformational. The dimensions proposed in the model are based on organizational business objectives. The result specify that IT value model can positively measure the post implementation impact of IT project. The framework can act as a guidelines for evaluating the IT project. Enhancing the IT value model by adding more dimensions can be the future work in this area of research which can improve the idea for IT evaluation.

\section{REFERENCES}

[1] Gartner, "Worldwide IT Spending Forecast," 2016. [Online]. Available: http://www.gartner.com/newsroom/ id/3482917. [Accessed: 01-Mar-2017].

[2] Vu, K. (2005). Measuring the Impact of ICT Investments on Economic Growth. Journal of Economic Growth.

[3] Dadayan, L. (2006, September). Measuring return on government IT investments. In Proceedings of the 13th European Conference on Information Technology Evaluation, Genoa, Italy (pp. 28-29).

[4] Saleem, F., Salim, N., Fayoumi, A. G., Al-Ghamdi, A. S., \& Ullah, Z. (2013). Comprehensive Study of Information and Communication Technology Investments: A Case Study of Saudi Arabia. International Information Institute (Tokyo). Information, 16(11), 7875. 
[5] Mittal, N., \& Nault, B. R. (2009). Research noteInvestments in information technology: Indirect effects and information technology intensity. Information Systems Research, 20(1), 140-154.

[6] Saleem, F., Salim, N., Fayoumi, A.G., and Alghamdi, A.A., A General Framework for Measuring Information and Communication Technology Investment: Case Study of Kingdom of Saudi Arabia, Advanced Machine Learning Technologies and Applications (First International Conference, AMLTA 2012, Cairo, Egypt. Proceedings, pp. 474-486.

[7] Harris, K., Grey, M. C., \& Rozwell, C. (2001). Changing the View of ROI to VOI-Value on Investment. Gartner Research Note, SPA-14-7250.

[8] Sabherwal, R., \& Jeyaraj, A. (2015). Information technology impacts on firm performance: an extension of Kohli and Devaraj (2003). Mis Quarterly, 39(4).

[9] Melville, N., Kraemer, K. L., \& Gurbaxani, V. (2004). Technology information an performance: Organizational integrative model of IT business value. MIS Quarterly, 28(2), 283-322.

[10] Brynjolfsson, E., \& Hitt, L. (1993). Is information systems spending productive?: new evidence and new results (pp. 47-64). MIT Sloan School of Management.

[11] Sai Hong, T., \& Ghobakhloo, M. (2013). IT investments and product development effectiveness: Iranian SBs. Industrial Management \& Data Systems, 113(2), 265-293.

[12] Ullah, Z., Al-Mudimigh, A. S., Al-Ghamdi, A. A. M., \& Saleem, F. (2013). Critical Success Factors of ERP Implementation at Higher Education Institutes: A Brief Case Study. International Information Institute (Tokyo). Information, 16(10), 7369.

[13] Al-Mudimigh, A. S., Ullah, Z., \& Saleem, F. (2009). A framework of an automated data mining systems using ERP model. International journal of computer and Electrical Engineering, 1(5), 651.

[14] Al-Ghamdi, A. A. M., \& Saleem, F. (2014, August). Enterprise application integration as a middleware: Modification in data \& process layer. In Science and Information Conference (SAI), 2014 (pp. 698-701). IEEE.

[15] Al-Mudimigh, A. S., Saleem, F., Ullah, Z., \& Al-Aboud, F. N. (2009, August). Implementation of Data Mining Engine on CRM-improve customer satisfaction. In Information and Communication Technologies, 2009. ICICT'09. International Conference on (pp. 193-197). IEEE.

[16] Al-Mudimigh, A. S., Ullah, Z., \& Saleem, F. (2009,
May). Data mining strategies and techniques for CRM systems. In System of Systems Engineering, 2009. SoSE 2009. IEEE International Conference on (pp. 1-5). IEEE.

[17] Al-Mudimigh, A. S., Saleem, F., \& Ullah, Z. (2009, May). The Effects of Data Mining in ERP-CRM ModelA Case Study of Madar. In WSEAS International Conference. Proceedings. Mathematics and Computers in Science and Engineering (No. 8). World Scientific and Engineering Academy and Society.

[18] Altalhi, A. H., AL-Malaise AL-Ghamdi, A., Ullah, Z., \& Saleem, F. (2017). Developing a framework and algorithm for scalability to evaluate the performance and throughput of CRM systems. Intelligent Automation \& Soft Computing, 23(1), 149-152.

[19] Maçada, A. C. G., Beltrame, M. M., Dolci, P. C., \& Becker, J. L. (2012). IT business value model for information intensive organizations. BAR-Brazilian Administration Revi

[20] Al-Ghamdi, A. A., and Saleem, F., "The Impact of ICT Applications in the Development of Business Architecture of Enterprises," Int. J. Manag. Stud. Res., vol. 4, no. 4, pp. 22-28, 2016.

[21] Irani, Z., Ezingeard, J. N., \& Grieve, R. J. (1997) Integrating the costs of a manufacturing IT/IS infrastructure into the investment decision-making process. Technovation, 17(11-12), 695-706.

[22] AGIMO, "Demand and Value Assessment Methodology," Canberra, Australia, 2004.

[23] Saleem, F., Salim, N., Altalhi, A. H., Abdullah, A. L., Ullah, Z., Baothman, F. A., \& Junejo, M. H. (2016). Comparative study from several business cases and methodologies for ICT project evaluation. International Journal of Advanced Computer Science \& Applications, 1(7), 420-427.

[24] Saleem, F., Salim, N., Altalhi, A. H., Ullah, Z., ALMalaise AL-Ghamdi, A., \& Mahmood Khan, Z. (2017). Assessing the effects of information and communication technologies on organizational development: business values perspectives. Information Technology for Development, 1-35.

[25] Saleem, F., Salim, N., Al-Ghamdi, A. A., and Ullah, Z., "Building framework for ict investments evaluation: Value on investment perspective," ARPN J. Eng. Appl. Sci., Vol. 10, No. 3, 2015.

[26] Aral, S., \& Weill, P. (2007). IT assets, organizational capabilities, and firm performance: How resource allocations and organizational differences explain performance variation. Organization Science, 18(5), 763 780 . 